\title{
The Koillismaa Deep Hole: insight to anomalous mafic intrusion
}

\author{
T. Karinen ${ }^{* 1}$, H. Salmirinne ${ }^{1}$, I. Lahti ${ }^{1}$, J. Konnunaho ${ }^{1}$, S. Heinonen ${ }^{2}$ and A. Salo ${ }^{3}$ \\ ${ }^{1}$ Geological Survey of Finland, P.O. Box 77, FI-96101 Rovaniemi, Finland \\ ${ }^{2}$ Geological Survey of Finland, P.O. Box 96, FI-02151 Espoo, Finland \\ ${ }^{3}$ Geological Survey of Finland, P.O. Box 1237, FI-70211 Kuopio, Finland \\ *E-mail: tuomo.karinen@gtk.fi
}

\begin{abstract}
Summary Geological Survey of Finland (GTK) is drilling a $3000 \mathrm{~m}$ long hole for solving mystery of deep geophysical anomaly zone located in the Koillismaa area, NE Finland. The diamond drilling campaign, Koillismaa Deep Hole, has been preceded by various geophysical surveys, such as gravity and magnetic measurement, seismic reflection soundings and AMT measurements which all show anomalous feature in depth.
\end{abstract}

\section{Introduction}

The anomaly zone, Koillismaa Deep Anomaly is ca. $60 \mathrm{~km}$ long zone connecting the distant parts of the $2.45 \mathrm{Ga}$ layered intrusion blocks of the Koillismaa (Alapieti 1982; Karinen 2010) and mafic-ultramafic Näränkävaara intrusion (Alapieti 1982; Järvinen et al. 2020) (Figure 1). The anomaly was observed already in 1950's since the earliest ground gravimetric and airborne geophysical measurements were performed. Therefore, the source of anomaly has been struggling the minds of geoscientists already for many decades. GTK started to drill a $3000 \mathrm{~m}$ long drill hole in the heart of the anomaly in September 2020, to finally collect rock samples from the source of the anomalous zone. In this abstract we briefly describe the background, geophysical studies and present stage of the ongoing drilling.

\section{Geophysical studies}

Most of the scientific contributions related to the Koillismaa Deep Anomaly have been geophysical studies (Piirainen et al. 1978; Saviaro 1976; Salmirinne \& Iljina 2003; Gislason et al. 2019). The anomaly zone is most distinctly observed and interpreted from gravity and magnetic surveys (Figure 2). The source of the anomaly is interpreted to be about $2.5-5 \mathrm{~km}$ wide with depth of the upper interface to country rock between 1 and $2 \mathrm{~km}$ below the present erosion level depending on the location along the anomaly. Interpretation of earliest AMTsurveys in 1970s brought up a weak conductivity contrast located in the same area with the gravity anomaly.

The latest geophysical surveys carried out by GTK were a seismic survey in 2018 and an AMT survey in 2019. The seismic reflection data was acquired along the road close to the drilling site with 90 wireless geophones with $20 \mathrm{~m}$ spacing and explosive sources with $40 \mathrm{~m}$ spacing (Gislason et al. 2019). The resulting seismic reflection profile shows prominent reflectors that are very likely due to lithological contacts or fracture zones that cause abrupt change of acoustic impedance within the subsurface (Figure 3). Furthermore, the AMT data confirmed the existence of the previously interpreted conductivity contrast. 


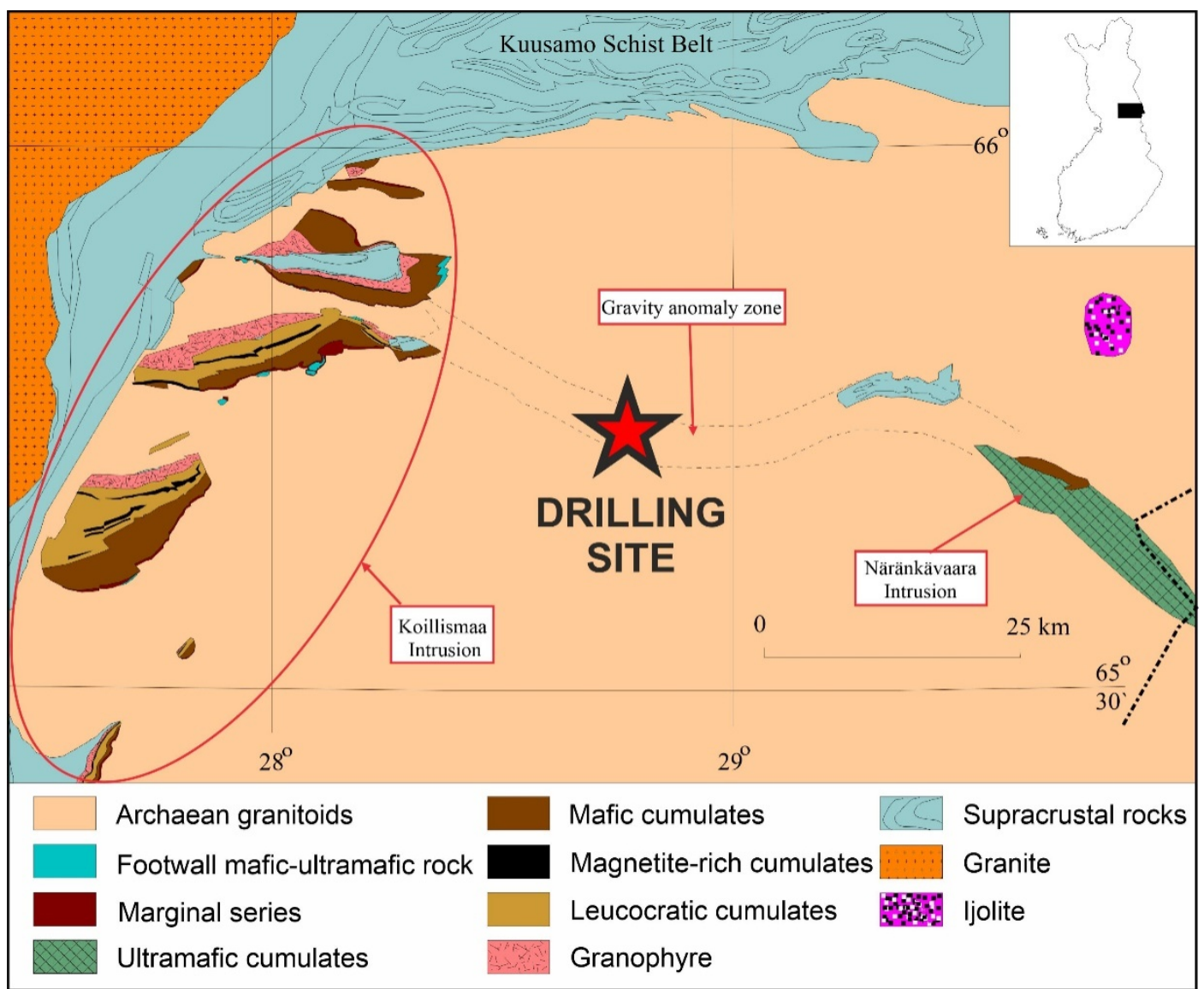

Figure 1. General geological map of the Koillismaa-Näränkävaara area.

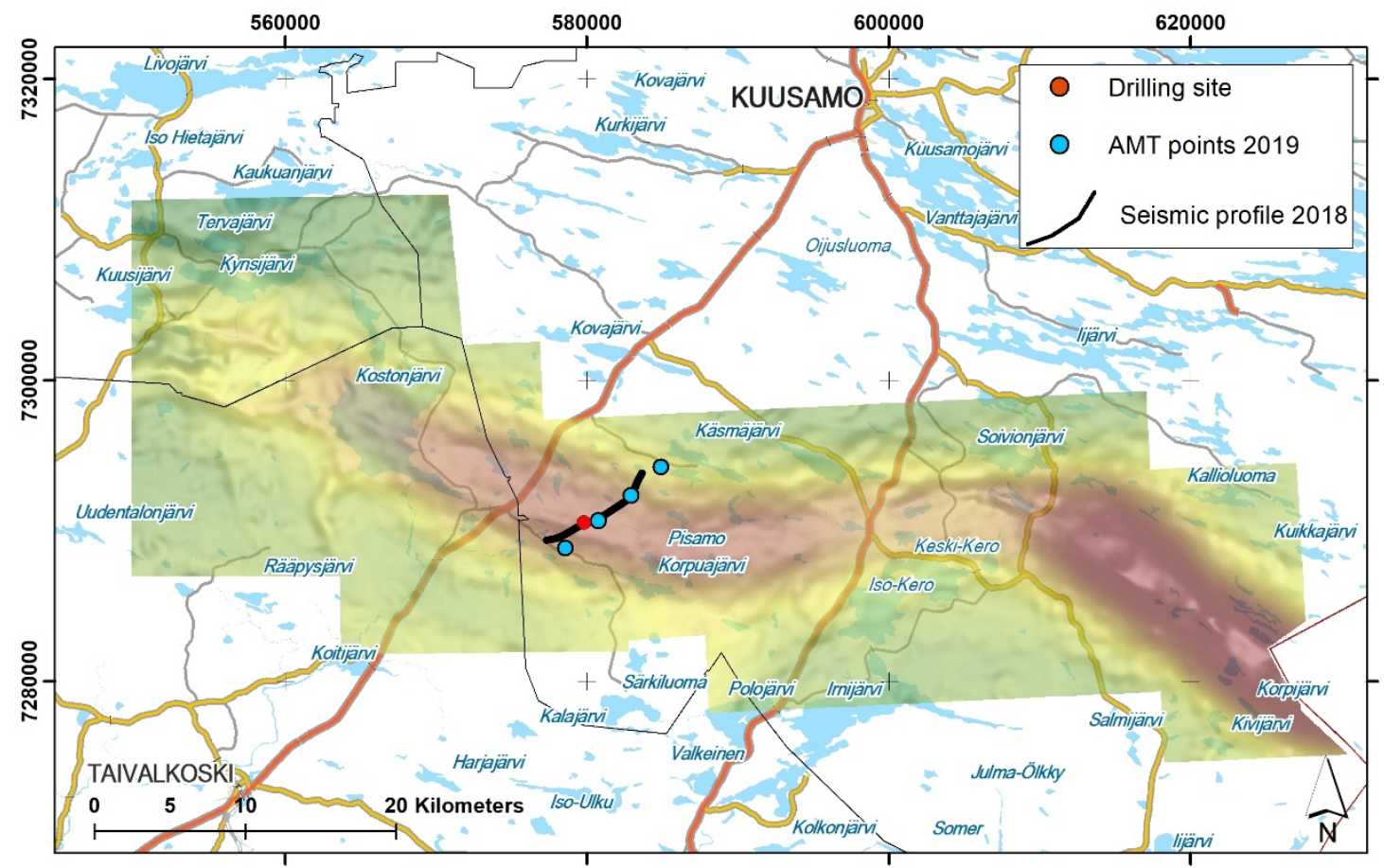

Figure 2. Drilling site on the regional gravity map. Locations of seismic profile 2018 and AMT surveys 2019 are plotted also. 


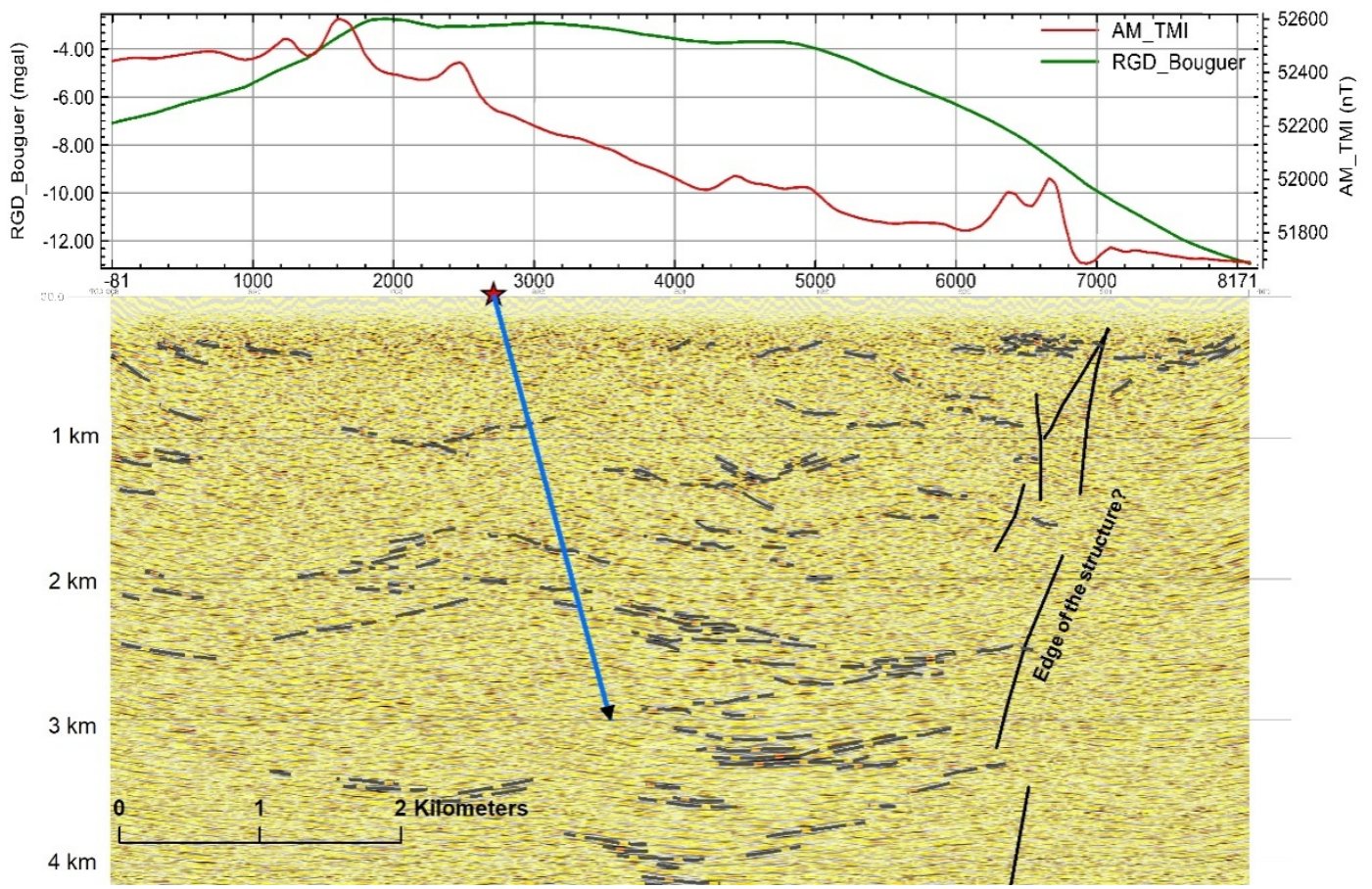

Figure 3. Planned drill hole projected to the seismic reflection profile. Bouguer gravity anomaly (RGD_Bouguer) and airborne magnetic (AM_TMI) profiles are plotted above the seismic section.

We believe that the anomaly reflects location of a gigantic chonolith-like feeder zone for the magmas of the exposed mafic-ultramafic intrusions in the Koillismaa. Alternatively, the anomaly could reflect the presence of mafic-ultramafic rocks representing some other magmatic episode than the $2.45 \mathrm{Ga}$ intrusions, for example, the Archaean greenstone belt near the Koillismaa area. This kind of voluminous mafic-ultramafic systems are globally rare, and therefore, the target is very likely an example of plume derived magmatism of Fennoscandian shield. In addition, large mafic-ultramafic bodies are favourable to host significant orthomagmatic sulfide and oxide deposits.

\section{Drilling campaign}

On surface level, the anomaly is traceable by a narrow breccia zone. However, the petrophysical properties of the breccia do not explain the geophysical anomaly, and therefore, the project started the diamond drilling campaign in order to collect sample material from the depth that would result in observed geophysical signature.

In September 2020, GTK started diamond drill campaign the Koillismaa Deep Hole to reach the anomaly. The drill core is planned to be up to $3000 \mathrm{~m}$ in length. Presently the drill core has reached a depth of $1722 \mathrm{~m}$. Luckily, we have been able to collect sample material which confirms that the source of anomaly is related to ultramafic cumulates, such as peridotite and pyroxenite (Figures $4 \mathrm{a}$ and $\mathrm{b}$ ). These rocks were penetrated at about $1.5 \mathrm{~km}$ depth, where also prominent change in seismic reflectivity is observed.

\section{Impact of the Koillismaa Deep Hole}

In addition to scientific contribution increasing the understanding of the Koillismaa intrusion geology and mineral potential, the deep drill hole site also provides scientific platform and test environment for future studies. These are, for example, development of survey technology, 3D modelling, studies of geothermal energy, deep groundwater and bedrock stability. 

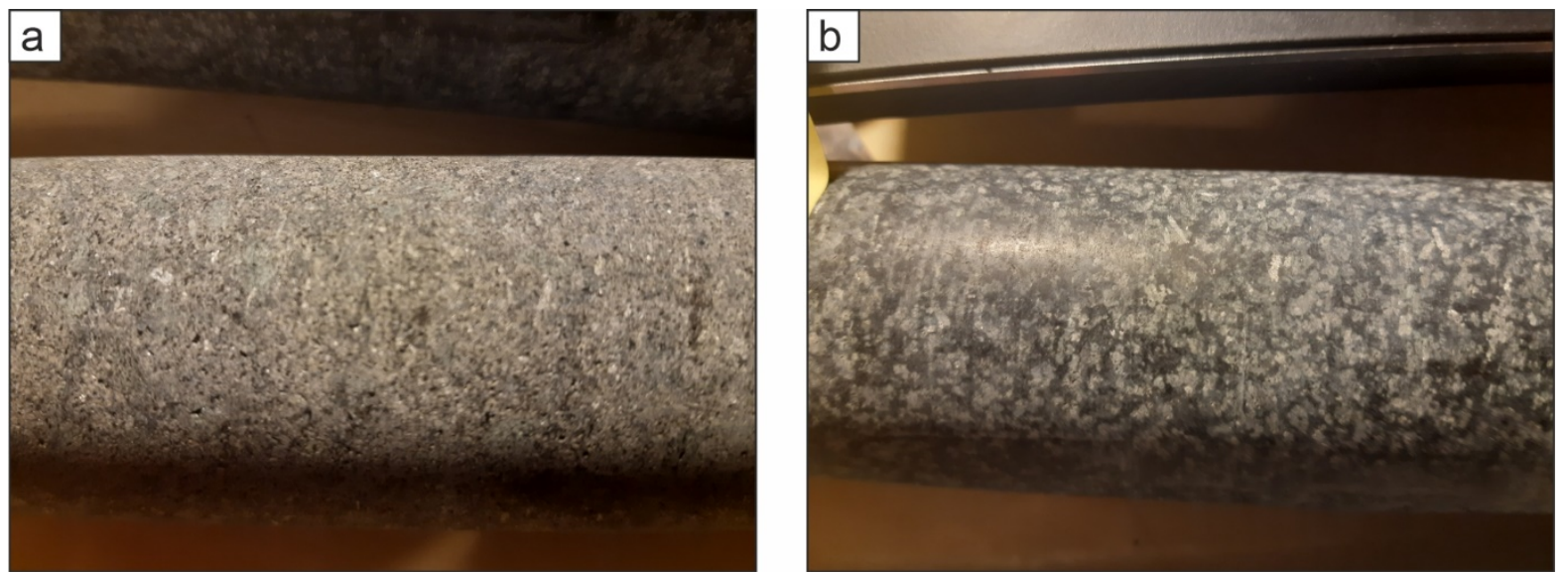

Figure 4. Samples from the depth. (a) Pyroxenite from $\sim 1430 \mathrm{~m}$. (b) Peridotite from $\sim 1545 \mathrm{~m}$ of the diamond drill core.

\section{References:}

Alapieti, T., 1982. The Koillismaa layered igneous cornplex, Finland - its structure, mineralogy and i geochemistry, with ernphasis on the distrubution of chromium. Geological Survey of Finland, Bulletin 319. $116 \mathrm{p}$.

Gislason, G., Heinonen, S., Salmirinne, H., Konnunaho, J. and Karinen, T., 2019. KOSE - Koillismaa Seismic Exploration survey: Acquisition, processing and interpretation. GTK:n työraportti - GTK Open File Work Report, $26 \mathrm{p}$.

Järvinen, V., Halkoaho, T., Konnunaho, J., Heinonen, J. \& Rämö T. 2020.Parental magma, magmatic stratigraphy, and reef-type PGE enrichment of the 2.44-Ga mafic-ultramafic Näränkävaara layered intrusion, Northern Finland. Mineralium Deposita 55, p. 1535-1560.

Karinen T., 2010. The Koillismaa Intrusion, northeastern Finland - evidence for PGE reef forming processes in the layered series. Geological Survey of Finland, Bulletin 404, $176 \mathrm{p}$.

Piirainen, T., Hugg, R, Aario, R., Forsström, L., Ruotsalainen, A. \& Koivumaa, S., 1978. Koillismaan malmikriittisten alueiden tutkimusprojektin loppuraportti 1976. Summary: The Report of the Koillismaa Research Project. Geologinen tutkimuslaitos. Research Report 18. 51 p.

Salmirinne, H. \& Iljina, M. 2003. Koillismaan kerrosintruusiokompleksin tulokanavamuodostuman painovoimatulkinta ja alueen malmimahdollisuudet (osa 1). Geologian tutkimuskeskus, Archive Report Q21/2003/1. $20 \mathrm{p}+5$ appendices.

Saviaro, K., 1976. Geofysikaalisia tutkimuksia Koillismaan gabrointruusioiden alueella. Lisensiaattityö, Oulun yliopiston geofysiikan laitos. $72 \mathrm{~S}$. PSMTP1/3-76-6. 